\title{
The Effect of Exogenously Applied Plant Growth Regulators on Plant Development of Saffron (Crocus sativus L.)
}

\author{
Aysun ÇAVUŞOĞLU ${ }^{1}$
}

\begin{abstract}
Plant growth regulators have important roles in plant growth and development. The externally applicable chemicals belong to different action classes and each one has a crucial and effective role at different plant growing stages. Saffron (Crocus sativus $\mathrm{L}$.) is one of the most important and valuable medicinal and aromatic plant, belongs to Iridaceae family. Because of impossibility of generative propagation in nature, growing can be maintened asexually with daughter corms occured each year. In this experiment, the effects of exogenously applied paclobutrazol, indole-3-butyric acid, zeatin and picloram on saffron developmental stages were studied. Data were focused on aerial part and corm related characters which is important in developmental findings in this plant. In the treatments, paclobutrazol (10 or $\left.20 \mathrm{mg} \mathrm{L}^{-1}\right)$, indole-3-butyric acid $\left(1\right.$ or $\left.3 \mathrm{mg} \mathrm{L}^{-1}\right)$, zeatin $\left(1\right.$ or $\left.3 \mathrm{mg} \mathrm{L}^{-1}\right)$ and picloram ( 5 or $10 \mathrm{mg} \mathrm{L}^{-1}$ ) were applied alone besides control to saffron 45 days after planting to the soil under greenhouse condition. According to the data picloram concentrations have a retardant role in nodium activation, leaf number and corm developmental characters (number, weight, diameter and yield of daughter corm) but cause the highest plant height $\left(60.98 \mathrm{~cm}\right.$ in $10 \mathrm{mg} \mathrm{L}^{-1}$ and $57.37 \mathrm{~cm}$ in $\left.5 \mathrm{mg} \mathrm{L}^{-1}\right)$. In $10 \mathrm{mg} \mathrm{L}^{-1}$ paclobutrazol treatments resulted as the best corm production ( $469 \mathrm{~kg} \mathrm{da}^{-1}$ ) than the other treatments and control. Zeatin at $3 \mathrm{mg} \mathrm{L}^{-1}$ concentration was found effective on the best nodium activation (2.81 active nodes/corm). In conclusion, saffron development is affected significantly by externally applied plant growth regulators under soil condition and the application methods can be progressed in studies on aimed parts of the plant.
\end{abstract}

Keywords: Crocus sativus, indole-3-butyric acid, paclobutrazol, picloram, zeatin

\section{Safran (Crocus sativus L.)'da Bitki Gelişimi Üzerine Dışarıdan Uygulanan Bitki Gelişim Düzenleyicilerinin Etkisi}

\begin{abstract}
ÖZET: Dışsal uygulanabilen kimyasallar olan ve farklı etki sınıfları içinde bulunan bitki gelişim düzenleyicilerinin her biri bitki büyüme ve gelişiminin farklı aşamaları üzerinde hayati ve önemli işlevlere sahiptir. Tıbbi ve aromatik bitkiler içinde en önemli ve değerli bitkilerden biri olan safran (Crocus sativus L.) Iridaceae familyasına ait olup, doğal olarak generatif yolla üretilmesi mümkün olmadığından bitki gelişimi aseksüel olarak her yıl meydana gelen yavru kormlardan sağlanmaktadır. Bu araştırmada dışsal olarak uygulanan paclobutrazol, indole-3-butyric acid, zeatin and picloram maddelerinin safran gelişimi üzerine etkileri çalışılmıştır. Bitki gelişimi için önemli parametreler olan korm ve toprak üstü aksamı ile ilişkili karakterlerle ilgili veriler toplanmıştır. Çalışmada kontrol parsellerinin yanında paclobutrazol, indole-3-butyric acid, zeatin ve picloram bitki dikiminden 45 gün sonra cam serada toprağa uygulanmıştır. Elde edilen verilere göre picloram konsantrasyonları nodyum aktivasyonu, yaprak sayısı ve korm gelişim özellikleri (korm sayısı, ağırlı̆̆ı çapı ve yavru korm verimi) için geciktirici bir rol oynarken, en yüksek bitki boyu $\left(10 \mathrm{mg} \mathrm{L}^{-1}\right.$ de $60.98 \mathrm{~cm}$ ve $5 \mathrm{mg} \mathrm{L}^{-1}$ de $\left.57.37 \mathrm{~cm}\right)$ elde edilmiştir. $10 \mathrm{mg} \mathrm{L}^{-1}$ paclobutrazol uygulamalarında, diğer uygulamalara ve kontrole nazaran en iyi korm verimine (469 $\left.\mathrm{kg} \mathrm{da}^{-1}\right)$ ulaşılmıştır. Zeatin $3 \mathrm{mg} \mathrm{L}{ }^{-1}$ konsantrasyonda en iyi nodyum aktivasyonu göstermiştir (2.81 aktif nodyum/korm). Sonuç olarak safran gelişimi önemli derecede dışarıdan toprağa uygulanan bitki gelişim düzenleyicilerinden etkilenmekte olup uygulama metodu gelişimi hedeflenen bitki kısmı göz önüne alınarak geliştirilebilir.
\end{abstract}

Anahtar kelimeler: Crocus sativus, indole-3-butyric acid, paclobutrazol, picloram, zeatin

Kocaeli Üniversitesi, Arslanbey Meslek Yüksekokulu, Gıda İşleme Bölümü, Kocaeli, Türkiye

Sorumlu yazar/Corresponding Author: Aysun ÇAVUȘOĞLU, cavusoglu@kocaeli.edu.tr 


\section{INTRODUCTION}

Saffron (Crocus sativus L.) is an autumn flowering, cormous perennial, Iridaceae family member plant. Although saffron plants have hermaphrodite flowers, there are some explanations about abnormalities at steps related with sexual propagation (Sampathu et al., 1984, Negbi et al., 1989, Renau-Morata et al., 2013) so cultivation of the plants is only possible via corm under field condition. Saffron stigmata is mainly used as medicinal and aromatic purposes. Demand of the stigmata is increasing as new applications in pharmacology emerge (Ríos et al., 1996). For this reason the studies on corm formation have increasing importance to obtain healthy and productive cultivation materials during the last decade. Therefore for this purpose some of the studies (Turhan et al., 2007, Amiri, 2008; Khan et al., 2011, Çavuşoğlu and Sülüşoğlu, 2012) have focused on effect of natural and chemical fertilization by applying to the soil in saffron. On the other hand there are a few studies (Aytekin and Ac1kgoz, 2008) related with usage of plant growth regulators for saffron corm production under the field condition. Mostly the studies (Plessner et al., 1990, Sharma et al. 2008, Zeybek et al., 2012, Devi et al., 2011, 2014, Cavusoglu et al., 2013) on the effects of plant growth regulators have been done in in vitro.

In some cases results of field experiments with cormous or bulbous plants can be more productive, relaible, efficient and applicable. Based on this idea in the study, the effects of external usage of plant growth regulators directly to the soil, as promoter or retardant under greenhouse condition, on growth characteristics as aerial parts and aboveground parts of saffron were evaluated.

\section{MATERIALS AND METHODS}

The greenhouse trial were conducted in two growing season in 2011-2012 and 2012-2013 independently under Kocaeli city in Turkey. Before planting of saffron corms the soil was analysed. For analysis the soil samples taken from in a depth of 0-20 cm. Results indicated that pH: 7.18, E.C: $846 \mu \mathrm{S} / \mathrm{cm}, \mathrm{CaCO}_{3}: 2.9 \%$ and organic material was $3.22 \%$. Saffron corms were provided from any-treated growing areas. $10-24 \mathrm{~mm}$ in diameter corms (varied between $0.78 \mathrm{~g}-6.44 \mathrm{~g}$ ) were choosen and placed $10 \times 10 \mathrm{~cm}$ distance between and within rows in $5 \mathrm{~cm}$ depth in to the soil in $15^{\text {th }}$ of September 2011 and $15^{\text {th }}$ of September 2012. Each sub-parcel was $0.18 \mathrm{~m}^{2}$ consisted 18 corms in equal size (equal to $299.8 \mathrm{~kg}$ corm $\mathrm{da}^{-1}$ ).

Experiments were conducted in a randomised block design (Figure 1.a) with three replication using 8 different applications $\left(10\right.$ or $20 \mathrm{mg} \mathrm{L}^{-1}$ paclobutrazol, 1 or $3 \mathrm{mg} \mathrm{L}^{-1}$ indole-butyric acid, 1 or $3 \mathrm{mg} \mathrm{L}^{-1}$ zeatin and 5 or $10 \mathrm{mg} \mathrm{L}^{-1}$ picloram) addition to control. The plant growth regulators [Paclobutrazol $\left(\mathrm{C}_{15} \mathrm{H}_{20} \mathrm{ClN}_{30}\right) \quad \mathrm{MW}=293.79 \mathrm{~g}$ mol $^{-1}$; Indole-3-butyric-acid (IBA) $\left(\mathrm{C}_{12} \mathrm{H}_{13} \mathrm{NO}_{2}\right)$ $\mathrm{MW}=203.24 \mathrm{~g} \quad \mathrm{~mol}^{-1} ;$ Zeatin $\left(\mathrm{C}_{10} \mathrm{H}_{13} \mathrm{~N}_{5} \mathrm{O}\right)$ $\mathrm{MW}=219.2 \mathrm{~g} \mathrm{~mol}^{-1}$; Picloram $\left(\mathrm{C}_{6} \mathrm{H}_{3} \mathrm{Cl}_{3} \mathrm{~N}_{2} \mathrm{O}_{3}\right)$ $\left.\mathrm{MW}=241.5 \mathrm{~g} \mathrm{~mol}^{-1}\right]$ were purchased from chemical componies. Used plant growth regulators were dissolved first in requisite solvents then after completed to 1 liter with distilled water. To each sub-parcel of treatments 1 liter solution and to each control parcel 1 liter distilled water (equal to $3.8 \mathrm{~m}^{3} \mathrm{da}^{-1}$ ) was applied directly to the soil at once as soil drench method 45 days after corm planting when initially plant growth observed. At the application time the rooted plants consisted at least 2 leaves, 1 nodium and plant height was approximately $10 \mathrm{~cm}$ (Figure 1.b). The treated plots were regularly irrigated with tap water in the same amount weekly.

Arial part characteristics, except flower, as plant height, leaf number and active nodium were recorded every month and data were evaluated when reached the maximum values. Aboveground characterisitics as number, weight, diameter and yield of daughter corm (bigger than $10 \mathrm{~mm}$ in diameter) were recorded at normal corm lifting time when leaves completely turned yellow, at $1^{\text {st }}$ week of May 2012 and 2013. Data were statistically analyzed for variance (ANOVA) and mean separation comparisons at $P \leq 0.05$ level performed by Duncan's Multiple Range Test. 


\section{RESULTS AND DISCUSSION}

According to data, characters of aerial and aboveground part of Crocus sativus showed different responces to the treatments. Paclobutrazol concentrations had positive responce on daughter corm diameter but had negative effect on plant height. Additionally at concentration of $10 \mathrm{mg} \mathrm{L}^{-1}$ paclobutrazol caused an increase in daughter corm number and healthy daughter corm yield statistically than control and the other treatments (Table 1, 2; Figure 1.g). The results are supported by Devi et al. (2011). In their study $1.7 \mu \mathrm{M}$ and $3.4 \mu \mathrm{M}$ paclobutrazol gave higher saffron corm production respectively than the other treatments in in vitro. The mentioned study was the rare one about paclobutrazol effect on Crocus sativus. On the other hand there are some studies on the other cormous, tuberous and bulbous plants. Francescangeli (2009) found that at certain concentration of paclobutrazol had negative effect on bud appearance in Iris $x$ hollandica Tub. by immersion methods. Steinitz et al. (1991) studied on Gladiolus grandiflorus x Gladiolus trisitis hybrid and it was emphasized that paclobutrazol responded limited leaf elongation and caused corm growth at $10 \mathrm{mg} \mathrm{L}^{-1}$ paclobutrazol by liquid-shake medium. Nagaraju et al. (2002) also found that effectiveness of $10 \mathrm{mg} \mathrm{L}^{-1}$ paclobutrazol and sugar in MS medium on formation of bigger corms in in vitro study in gladiolus. In the study on Caladium bicolor (Krug et al., 2007) it was found that paclobutrazol provided height control and shorter plants than untreated control by substrate drench method after initially plant development. The used method and result supported to the our experiment.

Indole-3-butyric acid (IBA), is one of the auxin type growth regulators and also showed effects in the saffron growth experiment. Although $1 \mathrm{mg} \mathrm{L}{ }^{-1}$ IBA showed more plant height (Figure 1.e), active nodium number, daughter corm number and daughter corm yield than control, its effect was medium when compaered with the other used plant growth regulators (Table 1,2). According to in vitro studies in saffron, when IBA used with 6-benzyladenine (BA), it was resulted that larger leaf lenght (Bhagyalakshmi, 1999). In another study, multiple shoot formation was high at secondary when $3 \mathrm{mg} \mathrm{dm}^{-3}$ IBA used with certain BA (Sharma et al., 2008). According to another study $1 \mathrm{mg} \mathrm{L}^{-1}$ IBA showed the best corm initiation and corm number than $2 \mathrm{mg} \mathrm{L}^{-1}$ IBA and control (Zeybek et al., 2012). Similarly in our study while $1 \mathrm{mg} \mathrm{L}^{-1}$ IBA gave the second best responce on corm yield, $3 \mathrm{mg} \mathrm{L}^{-1}$ IBA did not showed remarkable results. Application method as soil drench of our study was completely in differ from the most of saffron studies in which IBA was used.

Zeatin is a cytokinin and had remarkable effects on aerial part of saffron in the experiment. Especially $3 \mathrm{mg} \mathrm{L}^{-1}$ zeatin statistically effected nodium activation (Figure 1.d) than control and the other treatments (Table 1). Used zeatin concentrations gave lesser daughter corm weight and diameter than control and other used growth regulators when picloram treatments were ignored (Table 2). Plessner et al. (1990) found zeatin at $3 \mathrm{mg} \mathrm{L}^{-1}$ concentration effective on leaf number, leaf lenght and corm diameter in in vitro as well as other treatments.

Picloram has auxin-like properties (Colins et al., 1978) and mainly known with its herbicidal activities (WHO, 2009) especially on woody plants and broad-leaved weeds (IARC, 1991). At the same time picloram can be used in plant tissue culture tests for somatic embryogenesis in saffron (Devi et al., 2014) and in Agapanthus praecox ssp. minimus (Yaacob et al., 2012) for shoot proliferation in Lilium michiganense (Ault and Siqueira, 2008). Beside the monocots it also gave responce on somatic embryogenesis of Theobroma cacao L. (Zuyasna et al., 2012). According to our results used picloram doses showed the highest plant height, the lowest nodium activation and leaf number (Table 1). But according to personel observation plant aerial parts were not healthy looking (Figure 1.c). Growth of aboveground part of saffron also had the lowest values in number, weight, diameter and yield of daughter corm (Table 2). In addition daughter corms had dry-necrosis (Figure 1.f). It can be thought that this systemic chemicals strictly absorbed from soil and caused harmful effect at this concentrations under the used methods. 
Table 1. Results of data analysis for effect of growth regulators on aerial part characters in saffron*

\begin{tabular}{|c|c|c|c|}
\hline Plant Growth Regulators & $\begin{array}{l}\text { Plant Height } \\
(\mathrm{cm})\end{array}$ & $\begin{array}{c}\text { Activated Nodium } \\
\text { Number } \\
\text { (number/corm) }\end{array}$ & $\begin{array}{l}\text { Leaf number } \\
\text { (leaves/corm) }\end{array}$ \\
\hline Control & $48.78 \mathrm{~d}$ & $2.51 \mathrm{abcd}$ & $5.64 \mathrm{a}$ \\
\hline Paclobutrazol $\quad 10 \mathrm{mg} \mathrm{L}^{-1}$ & $45.93 \mathrm{e}$ & 2.43 bcde & $5.65 \mathrm{a}$ \\
\hline Paclobutrazol $\quad 20 \mathrm{mg} \mathrm{L}^{-1}$ & $44.97 \mathrm{e}$ & 2.23 cde & $5.32 \mathrm{a}$ \\
\hline $1 \mathrm{mg} \mathrm{L}^{-1}$ & $53.72 \mathrm{c}$ & $2.76 \mathrm{ab}$ & $5.62 \mathrm{a}$ \\
\hline $3 \mathrm{mg} \mathrm{L}^{-1}$ & $49.37 \mathrm{~d}$ & 2.49 abcde & $5.19 \mathrm{a}$ \\
\hline $1 \mathrm{mg} \mathrm{L}^{-1}$ & $50.08 \mathrm{~d}$ & $2.56 \mathrm{abc}$ & $5.30 \mathrm{a}$ \\
\hline $3 \mathrm{mg} \mathrm{L}^{-1}$ & $49.68 \mathrm{~d}$ & $2.81 \mathrm{a}$ & $5.62 \mathrm{a}$ \\
\hline Picloram & $57.37 \mathrm{~b}$ & $2.15 \mathrm{e}$ & $4.64 \mathrm{ab}$ \\
\hline \multirow[t]{2}{*}{ Picloram } & $60.98 \mathrm{a}$ & $2.19 \mathrm{de}$ & $4.12 \mathrm{~b}$ \\
\hline & $\begin{array}{l}\mathrm{LSD}=2.134 \\
\mathrm{~S} \tilde{\mathrm{x}}: 0.7183\end{array}$ & $\begin{array}{c}\mathrm{LSD}=0.31116 \\
\mathrm{~S} \tilde{\mathrm{x}}: 0.1049\end{array}$ & $\begin{array}{c}\mathrm{LSD}=0.8907 \\
\mathrm{~S} \tilde{\mathrm{x}}: 0.2998\end{array}$ \\
\hline
\end{tabular}

*Values followed by different letters differ from each other at $P \leq 0.05$ (Duncan's Multiple Range Test)

Table 2. Results of data analysis for effect of growth regulators on corm related characters in saffron*

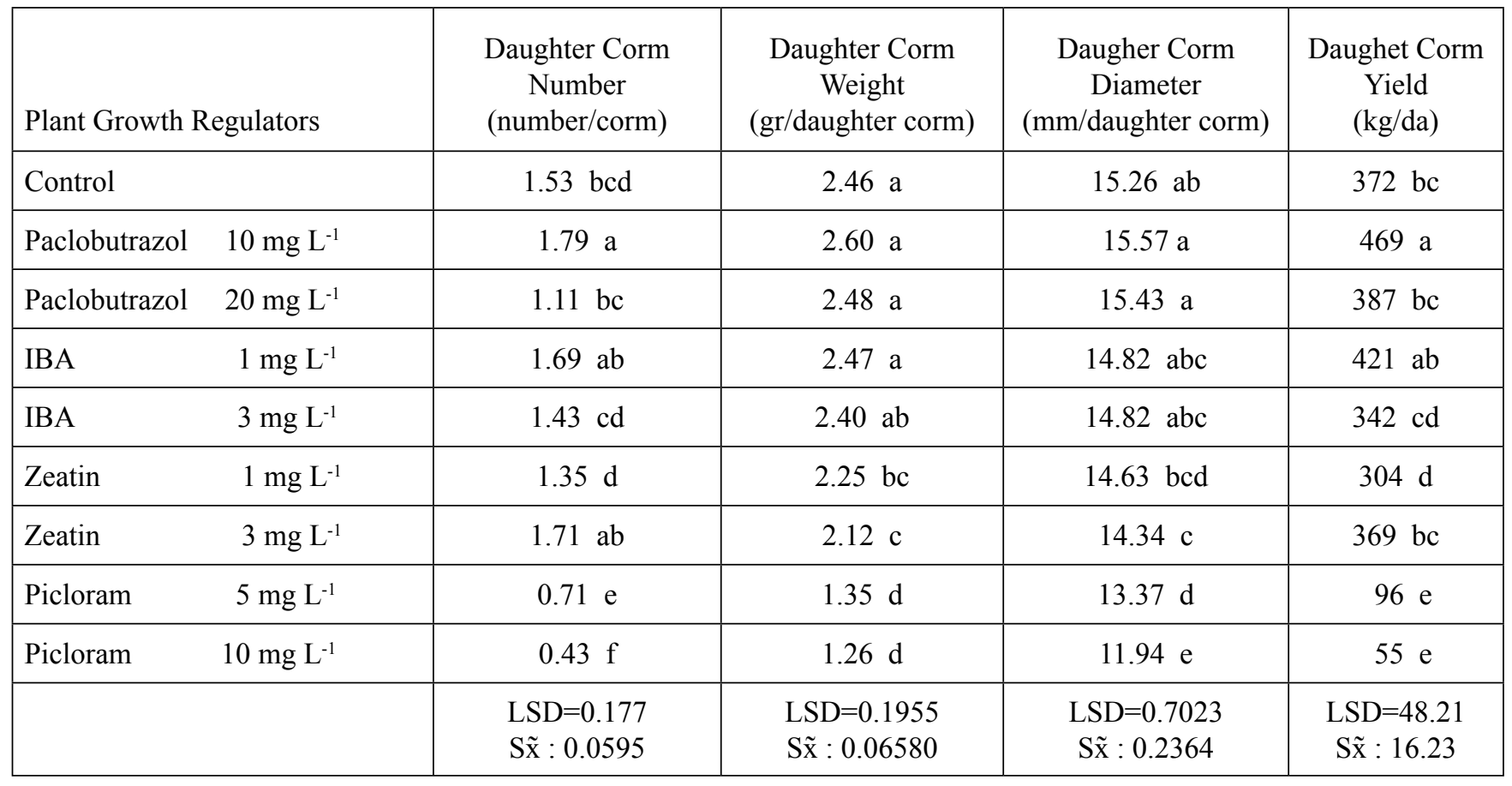

* Values followed by different letters differ from each other at $P \leq 0.05$ (Duncan's Multiple Range Test) 

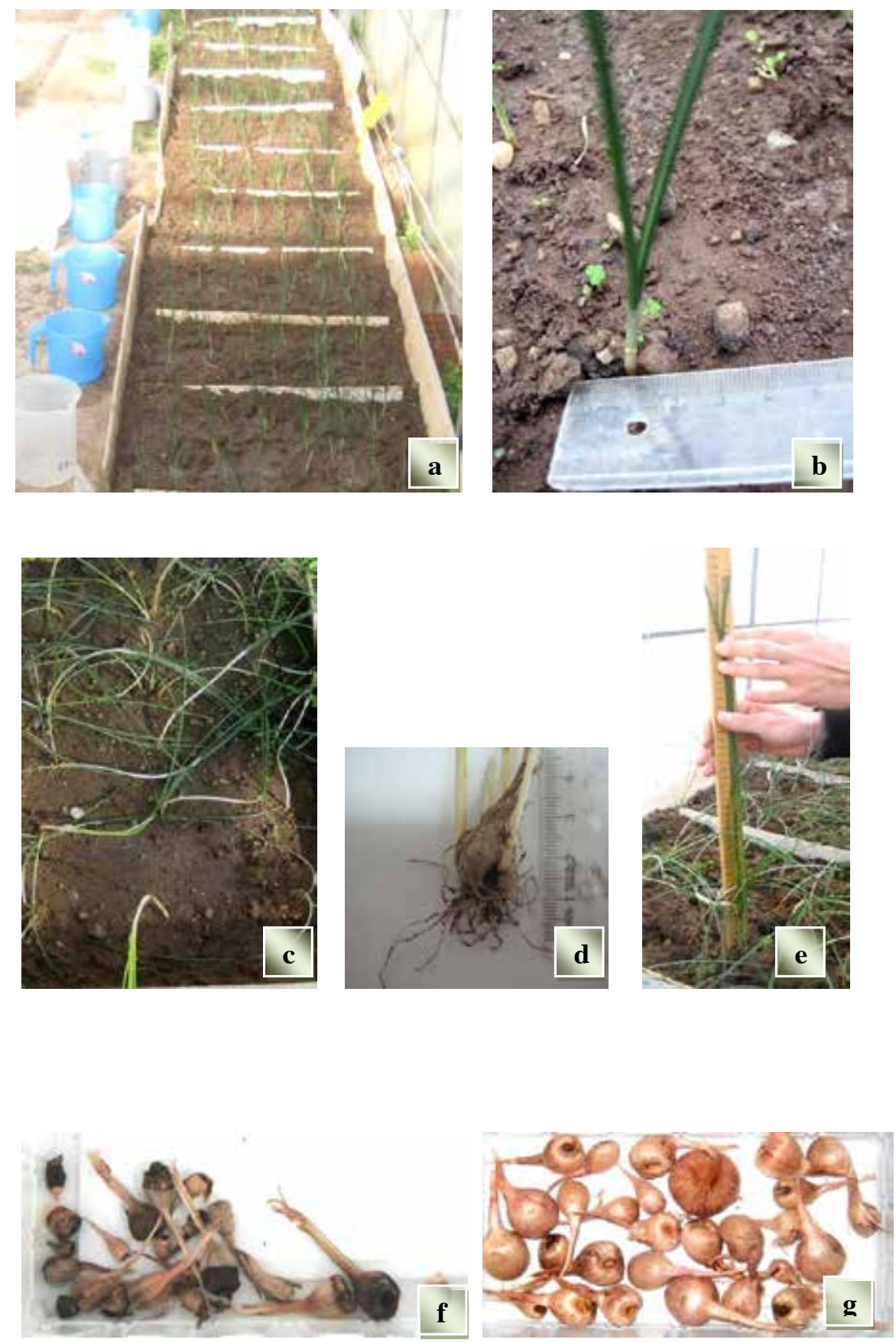

Figure 1. Experimental steps; a) One of the experimental block of randomized design, b) Plant condition at application time of plant growth regulators, c) Effect of $5 \mathrm{mg} \mathrm{L}^{-1}$ picloram on saffron aerial part, d) Nodium activation at $3 \mathrm{mg} \mathrm{L}^{-1}$ zeatin, e) Plant height measurement at 1 $\mathrm{mg} \mathrm{L}^{-1} \mathrm{IBA}, \mathrm{f}$ ) Effect of $10 \mathrm{mg} \mathrm{L}^{-1}$ picloram on saffron underground (corm) part, g) Effect of $10 \mathrm{mg} \mathrm{L}^{-1}$ paclobutrazol on saffron underground (daugher corm) part

\section{CONCLUSIONS}

In brief the experiment can be concluded that the experiment is one of the rare studies in methodological terms that using directly in to the soil as soil drench method for some used the plant growth regulators. When all data taken into consideration; paclobutrazol has an effect on plant height control and maximum corm production at used concentration. IBA also have effect at certain concentration on corm yield. Zeatin can be used in nodium activation. Picloram was found harmful at the both of used concentrations on underground part. After the premise experiment, in future work, a series 
of concentration of the growth regulators in different growing media with different application methods should be studied without ignoring toxicity and translocation of the plant growth regulators in saffron especially in stigma that is mainly used part. In addition economic analysis should be worked for the used methods with the used plant growth regulators in saffron.

\section{ACKNOWLEDGEMENTS}

This abstract presented at 1. National Plant Physiology Symposium(1-4 September, 2015, Erzurum/ Turkey) (Abstract Book p.92) in same content. The author thank Assoc.Prof.Dr. M. Sulusoglu for statistical analysis.

\section{REFERENCES}

Amiri ME, 2008. Impact of animal manures and chemical fertilizers on yield components of saffron (Crocus sativus L.). AmericanEurasian J. Agric\&Environ. Sci., 4(3): 274-279.

Ault JR, Siqueira SS, 2008. Morphogenetic response of Lilium michiganense to four auxin-type plant growth regulators in vitro. HortScience, 43(6): 1922-1924.

Aytekin A, Acıkgoz AO, 2008. Hormone and microorganism treatments in the cultivation of saffron (Crocus sativus L.) plants. Molecules, 13: 1135-1146.

Bhagyalakshmi N, 1999. Factors influencing direct shoot regeneration from ovary explants of saffron. Plant Cell, Tissue and Organ Culture, 58: 205-211.

Cavusoglu A, Sulusoglu M, Erkal S, 2013. Plant regeneration and corm formation of saffron (Crocus sativus L.) in vitro. Research Journal of Biotechnology, 8(12): 128-133.

Colins GB, Vian WE, Phillips GC, 1978. Use of 4-Amino-3,5,6trichloropicolinic acid as an auxin source in plant tissue cultures. Crop Science, 18(2): 286-288.

Çavuşoğlu A, Sülüşoğlu M, 2012. Saffron corm and habitus growth under nitrogen fertilized field condition. Tibbi ve Aromatik Bitkiler Sempozyumu Bildiriler Kitabı, Tokat, Türkiye. 156161.

Devi K, Sharma M, Singh M, Ahuja PS, 2011. In vitro cormlet production and growth evaluation under greenhouse conditions in saffron (Crocus sativus L.)- A commercially important crop. Eng. Life Sci., 11(2): 189-194.

Devi K, Sharma M, Ahuja PS, 2014. Direct somatic embryogenesis with high frequency plantlet regeneration and succssive cormlet production in saffron (Crocus sativus L.). South African Journal of Botany. 93: 207-216.

Francescangeli N, 2009. Paclobutrazol and cytokinin to produce iris (Iris $x$ hollandica Tub.) in pots. Chilean Journal of Agricultural Research. 69 (4): 509-515.

IARC, 1991. Picloram. IARC monographs on the evaluation of carcinogenic risks to human, Lyon-France. 53: 481-493.
Khan MA, Naseer S, Nagoo S, Nehvi FA, 2011. Behavior of saffron (Crocus sativus L.) corms for daughter corm production. Journal of Phytology. 3 (7): 47-49.

Krug BA, Whipker BE, McCall I, 2007. Caladium growth control with flurprimidol, paclobutrazol, and uniconazole. HortTechnology,17(3): 368-370.

Nagaraju V, Bhowmik G, Parthasarathy VA, 2002. Effect of paclobutrazol and sucrose on in vitro cormel formation in gladiolus. Acta Bot. Croat., 61(1): 27-33.

Negbi M, Dagan B, Dror A, Basker D, 1989. Growth, flowering, vegetative reproduction and dormancy in the saffron crocus (Crocus sativus L.). Isr. J. Bot., 38:95-113.

Plessner O, Ziv M, Negbi M, 1990. In vitro corm production in the saffron crocus (Crocus sativus L.). Plant Cell Tiss. Org. Cult., 20: 89-94.

Renau-Morata, B, Moya L, Nebauer SG, Segui-Simarro JM, ParaVega V, Gomez MD, Molina RV, 2013. The use of corms produced under storage at low temperatures as a source of explants for the in vitro propagation of saffron reduces contamination levels and increases multiplication rates. Ind. Crop Prod., 46: 97-104.

Ríos JL, Recio MC, Giner RM, Máňez S, 1996. An update review of saffron and its active constituents. Phytother. Res., 10: 189193.

Sampathu SR, Shivshankar S, Lewis YS, 1984. Saffron (Crocus sativus L.) cultivation, processing, chemistry and standardization. CRC Crit. Rev. Food Sci. Nutr., 20(2): 123157.

Sharma KD, Rathour R, Sharma R, Goel S, Sharma TR, Singh BM, 2008. In vitro cormlet development in Crocus sativus. Biol. Plantarum, 52(4): 709-712.

Steinitz B, Cohen A, Goldberg Z, Kochba M, 1991. Precocious gladiolus corm formation in liquid shake cultures. Plant Cell, Tissue and Organ Culture, 26: 63-70.

Turhan H, Kahriman F, Egesel CO, Gul MK, 2007. The effects of different growing media on flowering and corm formation of saffron (Crocus sativus L.). African Journal of Biotechnology, 6(20): 2328-2332.

WHO, 2009. The WHO recommended classification of pesticides by hazard and guidelines to classification, Stuttgard-Germany, $39-46$.

Yaacob JS, Yussof AIM, Taha RM, Mohajer S, 2012. Somatic embryogenesis and plant regeneration from bulb, leaf and root explants of African blue lily (Agapanthus praecox $s s p$. minimus). Australian Journal of Crop Science, 6(19): 14621470 .

Zeybek E, Önde S, Kaya Z, 2012. Improved in vitro micropropagation method with adventitious corms and roots for endangered saffron. Central Eur. J. Biol., 7(1): 138-145.

Zuyasna S, Hafsah S, Fajri R, Syahputra MO, Ramadhan G, 2012. The effect of picloram concentrations and explants types on the induction of somatic embryo on North Aceh Cocoa genotype. Proceedings of the 2nd Annual International Conference Syiah Kuala University \& The 8th IMT-GT Uninet Biosciences Conference Banda Aceh., 2(1): 395-398. 